\title{
INTERACTIONS BETWEEN MUSCULOSKELETAL DYSFUNCTION, EMOTIONAL DISTRESS AND CYTOKINES IN PATIENTS WITH CHRONIC LOW BACK PAIN SYNDROME
}

\author{
Daina Šmite', Gunta Ancāne'2, Pēteris Tretjakovs ${ }^{3}$ \\ Riga Stradins University, Department of Rehabilitation ${ }^{1}$ \\ Riga Stradins University, Department of Psychotherapy and Psychosomatic Medicine ${ }^{2}$ \\ Riga Stradins University, Institute of Experimental and Clinical Medicine ${ }^{3}$
}

\section{SUMMARY}

Despite different treatment methods, for approximately $30 \%$ of patients acute back pain turns into chronic pain syndrome which accompanied by disability creates remarkable material damage to patients themselves, to health care and to the society.

The aim of the study was to analyse the interaction between musculoskeletal dysfunction, emotional distress and related disability, and their underlying neuroimonological pathophysiological mechanisms, in patients with chronic low back pain syndrome.

The subjects were 43 patients, mean age $45 \pm 1.3$ years, with clinical diagnosis of lumbar spine disk pathology with chronic low back pain syndrome and present manifestation of emotional distress.

All patients had complex assessment that included lumbar spine and pelvic motor control tests, muscle and ligaments palpation tests, Hospital Anxiety and Depression Scale, PF subscale of SF-36 survey, Visual Analogue Scale, immunological analysis of blood to detect the level of cytokines.

The results approved interaction $(p<0.05)$ between motor control and palpation tests results, emotional distress features and pain intensity. Therefore musculoskeletal dysfunction in patients with chronic low back pain is connected both with physical and psycho-emotional factors, which has to be taken into account both when evaluating functional tests and during the treatment process. Clinically important finding is that limitation in physical activities in chronic low back pain patients are affected both by motor control impairment and depression symptoms, as well as pain intensity, which has to be remembered during rehabilitation planning process. Some of cytokines (TNF-a, IL-6, IL-8, IL-10, IL-2) correlated with emotional disturbances physical disturbances, pain syndrome characteristics and physical disability in patients with chronic low back pain. IL-10 and IL-8 appeared to be two of the most characteristic cytokines. It is interesting to note, that in literature studies have approved the role of IL-10 in the pathogenesis of chronic, widespread pain syndrome, but IL-8 has been shown in the role of the pathogenesis of radicular pain syndrome in patients with lumbar spine disk pathology $[1,2]$. Studies of cytokines extend the understanding of bio-psycho-social aspects of chronic pain syndrome pathogenesis therefore improving process of assessment, clinical reasoning and therapy.

Keywords: musculoskeletal dysfunction, emotional distress, chronic pain, cytokines.

\section{INTRODUCTION}

Chronic low back pain problem is a challenge for scientists as well for clinical practitioners. Still unanswered remains the question why on the background of overall increasing well-being and medical development the number of patients suffering from lower back pain is not decreasing but it increases and becomes the main problem for economically active patients. Spine disease is one of the most common causes of disability and absence from work (13\% of the total sick-leave time) and one of the most common reasons that people seek healthcare $(10 \%$ of the number of all visits to doctor) [3, 4].

Despite different treatment methods, for approximately $30 \%$ of patients acute back pain turns into chronic pain syndrome which accompanied by disability creates remarkable material damages to patients themselves, to health care and to the society in general. Due to the increase in chronic back pain and disability caused by it, it has been called the social epidemic, the cause of which has been related to cultural and psychosocial factors, as no relevant biological pathology changes are observed. The results of clinical studies, performed during last 10 years have confirmed a model of the multidimensional lower back pain, integrating physical, emotional and social pathogenetic factors [4, $5,6,7,8]$.
In our previous research we found that chronic low back pain patients with same clinical diagnosis lumbar spine disk pathology with radiculopathy - differed by their emotional state and could be divided into two clinically diverse subgroups - patients with emotional distress symptoms and patients without them, generating the necessity for various treatment and rehabilitation tactics [9]. Emotional factors are currently viewed as important determinants in pain perception and behaviour. Psychological processes are not merely a reaction to pain, but they are an integral part of pain perception [6, $7,8,10]$.

To understand complicated pathogenetic mechanisms in case of chronic pain, many neuroimmunological studies have been carried out during last few years, where pathogenetic mechanisms are analysed at the molecular level (cytokines) [11, 12].

The aim of the study was to analyse the interaction between musculoskeletal dysfunction (motor control impairment, muscle tension), emotional distress (elevated level of anxiety, clinically significant symptoms of depression) and related disability, as well as their underlying neuroimonological pathophysiological mechanisms (serum level of cytokines), in patients with chronic low back pain syndrome. 
The material. The subject were the patients who were sent to rehabilitation and who were in the rehabilitation centre from 2006.09.01 till 2008.09.01 and corresponded to the study inclusion criteria: patients with clinical diagnosis of lumbar spine disk pathology with radiculopathy (after ICD -10 classification: M 51.1.), who had radiologicaly approved L4-L5 and/or L5-S1 intervertebral disc(s) herniation, whose primary complaint was low back pain in duration more than 3 months, with or without irradiation and who manifested emotional distress (Hospital Anxiety and Depression Scale scores of depression and/or anxiety subscales $\geq 7$ points), whose age was from 18 to 60 years and who agreed to participate in the study. We excluded patients who had some of the study exclusion criteria: muscle strength in lower extremities less than 3 grades (after Kendall); additional disease and/or traumatic injury (unrelated to the spine) which causes a functional limitation; somatoform disorder (after ICD-10 classification: F 45) or another psychiatric additional disease; spinal pathology, which is connected with infectious process, autoimmune or metabolic disorder, traumatic injury, neoplastic process (primary tumor or metastases) or internal organ pathology; congenital spine disorders and spine development anomaly; cauda equina syndrome; spinal stenosis (clinical manifestation or radiological findings); previously carried out stabilising spine surgery or more than one level of microdiscectomia; microdiscectomia lasting less than two months; pregnancy and less than 2 years after childbirth.

As a result, we enrolled a total of 43 patients including 18 (41.9\%) males and 25 (58.1\%) females. The age of the patients ranged from 24 to 55 years, their mean age $45 \pm 1.3$ years. The mean age of men were $43.0 \pm 1.6$ years, women $-45.1 \pm 1.5$ years. According to an independent sample $t$ test there were no statistically significant differences between men and women in their mean age $(t=1.35 ; p=0.21)$. All assessment data of enrolled patients were complete and possible to include in the data analysis of the study.

The procedure. The complex assessment of included patients was performed during the first 48 hours after admission to the rehabilitation centre. The assessment results were documented in the evaluation protocol. All completely obtained assessment data were collected and processed by mathematical statistical methods. The study was conducted in compliance with ethical principles (in accordance with the Declaration of Helsinki). There is a positive statement of Ethics Committee for the study.

The assessment methods. 1. In the assessment of musculoskeletal dysfunction we used lumbar spine and pelvic motor control tests: Active straight leg raising test (ASLR) [13] - standardized functional test with proved reliability and sensitivity in patients with low back pain syndrome. This test assesses the ability of pelvis to transfer load from lumbar spine to legs, therefore it is indicative for stability of lumbar spine and pelvis. Trendelenburg test [14] - this test was originally designed to evaluate hip function, but in recent years, the studies have shown that the test assesses motor control of pelvis and lumbar spine in weight-bearing position. The test is a standardized functional test with proved reliability. Both tests were interpreted by a four-point scale for each leg: (0) has no special effort and shows no objective signs of disturbance, (1) is difficult, but shows no objective signs of disturbance, (2) is difficult and we can observe objective signs of disturbance, (3 ) cannot perform/pain. For summarizing the results, we used the overall results of both legs which were obtained by summing the test result for right and left leg. Thus, the overall test result could be a range of 0 to 6 points; lower scores indicated better lumbar spine and pelvic motor control.

To evaluate the muscle tension, palpation test was used. We palpated and assessed $m$. erector spinae pars lumborum, pars thoracica and pars cervicalis, m. quadratus lumborum, postural muscles of pelvic girdle $(m$. tensor fasciae latae un fascia lata, $m$. biceps femoris un $m$. semitendinosus, $m$. semimembranosus, $m$. ileopsoas), postural muscles of shoulder girdle (m. trapezius upper part, $m$. levator scapulae, $m$. pectoralis minor and $m$. sternocleidomastoideus). Muscles were palpated at both sides (left and right). During palpation test, we evaluated the tension of muscle or ligament which was interpreted by grades from 0 to 3 where $(0)$ is not excessive tension (strain), (1) mild, (2) moderate, (3) marked tension (strain). Summarizing the results, we used the overall test results for both sides which were obtained by summing the palpation test result from right and left side. Thus, the overall test result could range from 0 to 6 points, lower scores indicated lower tension.

2. Evaluation of emotional distress was performed by Hospital Anxiety and Depression Scale (HADS) which detects the present level of anxiety and expression of depressive symptoms [15]. (In the study we used Latvian version of the scale. The license and the translation was from the National Foundation for Educational Research (nferNelson)); in the pilot study, the Latvian version of HADS had shown good internal consistency and reliability (Cronbach's alpha 0.892)). HADS is a selfreported questionnaire that consists of 14 statements, 7 for anxiety and 7 for depression. For each statement the patient had to give a response regarding how he (she) had felt during the last week (including the day of examination);

3. To assess the physical disability, we used SF-36® Health Survey Physical Functioning Subscale SF-36 that is a standardized, reliable self-reported questionnaire [16]. Low score of physical Functioning (PF) subscale indicates limitation in physical activities (including washing and dressing) due to health problems, while high score indicates ability to carry out different types of physical activity, including very difficult, without any restriction; In the study the Latvian version of the questionnaire was used (permission for use of the Latvian language translation was received from QualityMetric); in the pilot study, the Latvian version of SF-36 produced good internal consistency and reliability (Cronbach's alpha 0.982)); 
4. Visual Analogue Scale (VAS) was used to assess current low back pain intensity, and the duration (months) of current low back pain episode was recorded; general socio-demographic data for general group description were found out.

Immunological Analysis of Blood Serum was used to detect the level of cytokines. For the detection of cytokines, we used immunological analysis based upon XMAP technology using LUMINEX 200 system (USA) and LINKOplex cytokine's analysis kits (USA) (multitiplex fluoriscence - multidetection system). We detected and analysed IL-2, IL-4, IL-6, TNF-a, IL-8, IL-10, IL-1a, IL-1b, and INF-g levels in blood serum.
Statistical methods. Data processing was done using the computer program SPSS. To analyse the general characteristics of the patients, we used descriptive statistics (mean values, standard deviation, minimum and maximum values). For the assessment of interaction and relationships correlation analysis, we calculated Spearman's correlation coefficients between the individual indicators. In order to determine simultaneous impact of several factors to one dependent factor, multiple linear regression analysis was used. The statistical analysis rejected the null hypothesis and accepted the alternative hypothesis if the test of materiality levels were less than $5 \%(p<0.05)$.

\section{RESULTS OF THE STUDY}

The general description. All analysed patients were employed at the current moment, and all of them were on sick-leave for their low back pain episode. The main risk factors at workplace recorded were: prolonged static loads (38 (88.4\%), psychological stress (35 (81.4\%)) and hard physical work $(27(62.8 \%))$. All patients were married and lived together with spouse and children.

Low back pain syndrome: the vast majority of patients $(40(93 \%))$ had overall low back pain history for more than 5-7 years, but the other 3 patients mentioned that their first low back pain episode was before 8-10 years. All patients described their pain as recurrent with aggravation episodes.

Current low back pain episode in duration was from 4 to 24 months, average $8.8 \pm 5.6$ months. To describe pain localisation 23 (53.5\%), patients remarked low back region with irradiation to the leg, but the others 20 $(46.5 \%)$ remarked only in the region of lower back and / or buttocks. Current low back pain intensity (after VAS from 0 to 10) was within 2 to 6.4 points, average $4.2 \pm 1.2$ points.

Musculoskeletal dysfunction: all analysed patients had marked low back and pelvic girdle motor control impairment, that was detected by both motor control tests: ASLR test results in $38(88.4 \%)$ patients were 4 or 5 points, in other $5(11.6 \%)-3$ points; Trendelenburg test: most frequently obtained result was 5 or 6 points (in $34(79.1 \%)$ patients), in other $9(20.9 \%)$ patients' test result was 3 or 4 points). In all analysed patients we detected excessive tension in m.erector spinae (M $\pm \mathrm{SD}$ : pars lumborum $5.1 \pm 1.1$, pars thoracica $4.5 \pm 1.1$, pars cervicalis $4.6 \pm 1.3$ ), pelvic girdle muscles (in average): $4.5 \pm 1.0$, shoulder girdle muscles (in average): $5.1 \pm 0.9$.

Emotional distress: all analysed patients elevated the level of their anxiety: HADS anxiety subscale score was within 8 to 12 points, on average $9.2 \pm 1.1), 36(83.7 \%)$ of patients also had clinically significant symptoms of depression (HADS depression subscale score $\geq 7$ points): for all analysed patients, HADS depression subscale score varied from 6 to 12 points, on average $8.5 \pm 2$.

The correlation analysis. Relationships between emotional distress and musculoskeletal dysfunction features. Spearman's correlation analysis revealed relevant $(p<0.05)$ relationship between motor control and palpation tests results, and emotional distress features (Table). Present pain intensity demonstrated correlation with level of anxiety $(R=0.543, p=0.021)$ and depression symptoms $(R=0.325, p=0.013)$. Current pain intensity also presented significant relationship with musculoskeletal dysfunction (Table).

Relationships between cytokines and current pain syndrome. Correlation analysis showed relationship $(p<0.05)$ between pain intensity and levels of the following cytokines: IL-2 $(R=-0.32 ; p=0.02)$, IL1a $(R=0.33, p=0.002)$, IL-8 $(R=0.30 ; p=0.028)$, $\mathrm{IL}-1 \mathrm{~b}(\mathrm{R}=0.20 ; p=0.04)$. Current pain episode duration presented correlation $(p<0.05)$ with IL-6 $(R=0.33$; $p=0.01), I L-1 a(R=0.39 ; p=0.02), I L-2(R=-0.30$; $p=0.032), I L-10(R=-0.25 ; p=0.03), I N F-g(R=0.21$; $\mathrm{p}=0.03$ ).

Relationships between cytokines and emotional distress features. Depression symptoms revealed correlation with IL-6 $(R=0.40 ; p=0.003)$, IL-1a $(R=0.38 ; p=0.01), I L-10(R=-0.213 ; p=0.037), I N F-g$ $(R=-0.22 ; p=0.041), I L-4(R=0.26 ; p=0.044)$. Level of anxiety correlated with IL-8 $(R=0.39 ; p=0.01)$, IL-6 $(R=0.40 ; p=0.01), I L-1 a(R=0.31 ; p=0.03), I L-4$ $(R=0.30 ; p=0.03)$.

Relationships between cytokines and musculoskeletal dysfunction characteristics. Analysis revealed that both motor control test results correlated with some cytokines: IL-10 (ASLR: $R=-0.37 ; p=0.02$; Trendelenburg: $R=-0.41 ; p=0.02), I L-2(R=-0.41$, $p=0.02 ; R=-0.51 ; p=0.01)$, INF-g $(R=-0.31 ; p=0.01$; $R=-0.41 ; p=0.01)$ un TNF-a $(R=0.36 ; p=0.03$; $R=0.35 ; p=0.01$ ).

Results demonstrated relationship $(p<0.05)$ between muscle tension level and level of cytokines: m.erector spinae pars lumborum: IL-8 $(R=0.25$; $p=0.04), I L-6(R=0.40 ; p=0.021), I L-10(R=-0.46$; $p=0.03)$, INF-g $(R=0.32 ; p=0.03)$, m.tensor fascia latae and 'hamstring' muscles group tension level revealed correlation $(p<0.05)$ with the same cytokines (IL-8, IL-10, IL-6, INF-g).

Relationship between cytokines and the level of physical disability. PF of SF-36 correlated $(p<0.05)$ with IL-2 ( $R=0.54 ; p=0.002), I L-10(R=0.32 ; p=0.02)$, INF-g $(R=0.32 ; p=0.02), I L-8(R=-0.29 ; p=0.03)$, IL-1a $(R=-0.23 ; p=0.03)$. 
Multiple linear regression analysis. We found that the level of physical disability (ability to do physical activities, PF SF-36) were significantly $(p<0.05)$ affected by present pain intensity (beta $=-0.626 ; p=0.020$ ), lumbar and pelvic motor control impairment (ASLR test: beta $=-0.412 ; p=0.021)$ and depression symptoms $($ beta $=-0.452 ; p=0.011)$.

Table. Results of Spearman's correlations $(\mathbf{R}, \mathbf{p})$ between emotional distress, musculoskeletal dysfunction characteristics and pain intensity

\begin{tabular}{|c|c|c|c|c|}
\hline \multirow{2}{*}{\multicolumn{2}{|c|}{$\begin{array}{l}\text { Musculoskeletal dysfunction characteristics and pain } \\
\text { intensity }\end{array}$}} & $\begin{array}{l}\text { HADS Anxiety } \\
\text { Subscale }\end{array}$ & $\begin{array}{l}\text { HADS Depression } \\
\text { Subscale }\end{array}$ & Pain intensity (VAS) \\
\hline & & $\begin{array}{l}\mathrm{R} \\
\mathrm{P} \\
\end{array}$ & $\begin{array}{l}\mathrm{R} \\
\mathrm{P} \\
\end{array}$ & $\begin{array}{l}R \\
\mathrm{p}\end{array}$ \\
\hline \multirow[t]{2}{*}{ Motor control tests results } & ASLR & $0.363 * 0.002$ & $\begin{array}{l}0.276 \\
0.088\end{array}$ & $\begin{array}{l}0.108 \\
0.500\end{array}$ \\
\hline & Trendelenburg & $0.302 * 0.002$ & $\begin{array}{l}0.021 \\
0.901\end{array}$ & $\begin{array}{c}0.385^{* *} \\
0.001\end{array}$ \\
\hline \multirow{3}{*}{$m$. erector spinae tension } & Lumbar part & $0.452 * * 0.001$ & $\begin{array}{c}0.458^{* *} \\
0.001\end{array}$ & $\begin{array}{c}0.521^{* *} \\
0.001\end{array}$ \\
\hline & Thoracic part & $0.311 * 0.011$ & $\begin{array}{c}0.299 * \\
0.015\end{array}$ & $\begin{array}{l}0.029 \\
0.858\end{array}$ \\
\hline & Cervical part & $\begin{array}{l}0.116 \\
0.356\end{array}$ & $\begin{array}{l}0.127 \\
0.308\end{array}$ & $\begin{array}{l}0.217 \\
0.067\end{array}$ \\
\hline \multicolumn{2}{|c|}{ m. tensor fascia latae tension } & $\begin{array}{c}0.361^{*} \\
0.014\end{array}$ & $\begin{array}{c}0.352 * * \\
0.001\end{array}$ & $\begin{array}{c}0.337^{*} \\
0.023\end{array}$ \\
\hline \multicolumn{2}{|c|}{$\begin{array}{c}\text { Group: } m \text {. semitendinosus } m \text {. emimembranosus } \\
m \text {. biceps femoris }\end{array}$} & $\begin{array}{c}0.301 * * \\
0.001\end{array}$ & $\begin{array}{c}0.421^{* *} \\
0.001\end{array}$ & $\begin{array}{c}0.211^{*} \\
0.031\end{array}$ \\
\hline \multicolumn{2}{|c|}{ Lig. sacrotuberale } & $\begin{array}{l}0.110 \\
0.431\end{array}$ & $\begin{array}{c}0.421 * * \\
0.001\end{array}$ & $\begin{array}{l}0.212 \\
0.055\end{array}$ \\
\hline \multicolumn{2}{|c|}{ Long dorsal ligament } & $\begin{array}{l}0.141 \\
0.466\end{array}$ & $\begin{array}{c}0.366^{*} \\
0.022\end{array}$ & $\begin{array}{l}0.091 \\
0.671\end{array}$ \\
\hline \multicolumn{2}{|c|}{ m. levator scapulae } & $\begin{array}{c}0.321 * \\
0.043\end{array}$ & $\begin{array}{c}-0.371 * \\
0.023\end{array}$ & $\begin{array}{l}0.245 \\
0.056\end{array}$ \\
\hline \multicolumn{2}{|c|}{ m. trapezius upper part } & $\begin{array}{c}0.318^{*} \\
0.032\end{array}$ & $\begin{array}{c}-0.412 * \\
0.015\end{array}$ & $\begin{array}{c}0.266^{*} \\
0.041\end{array}$ \\
\hline
\end{tabular}

Note. ${ }^{*}$ - significiant correlation $p<0.05 ;{ }^{* \star}-$ significiant correlation $p<0.01$.

\section{DISCUSSION}

The group of analysed patients was homogeneous enough (according to pain characteristics, structural pathology of spine (all subjects had a basic diagnosis of lumbar spine disc pathology with radiculopathy and radiologically confirmed lumbar spine disc (-s) degeneration with impact on nerve root), emotional state (all patients had emotional distress) that made correlation analysis feasible.

Our study results confirmed relevant $(p<0.05)$ interaction between emotional distress and musculoskeletal dysfunction in chronic low back pain patients. It is clinically important to point out relationship between elevated level of anxiety and both motor control test results and extensive muscle tension. Connection between excessive muscle tension, pain intensity and anxiety level is frequently recognized in clinical praxis and described in literature [17]. But we also have to bear in mind direct interaction between anxiety and motor control impairment. It has to be taken into account both in the process of examination and interpretation of functional tests, and in the process of treatment.
The study results confirmed that in association with muscle and ligament tension assessment, interpretation and further treatment planning, we need to pay attention that were is complex musculoskeletal dysfunction, e. g. excessive muscle tension has been found not only in low back and pelvic region, but also in upper spine and shoulder girdle, and it has direct connection $(p<0.05)$ with anxiety, and some of muscles - with depression. Therefore there is a necessity for further research to explore physiotherapy methodology both in the assessment and the therapy of muscle and ligament tension.

Results of multiple regression analysis revealed that subjective perception of limitation in physical activities is affected both by motor control impairment and depression symptoms, as well as pain intensity. Worse health related to quality of life that is characterised by more expressed disability in patients with emotional disturbances, which has also been described by other authors $[18,19]$.

In accordance with recent scientific achievements, immunological analysis to determine the levels of cytokines in blood serum was included in our study, 
and it extended the understanding about bio-psychosocial aspects of chronic low back pain syndrome pathogenesis. Some of cytokines (TNF-a, IL-6, IL-8, IL$10, \mathrm{IL}-2$ ) correlated with emotional disturbances (anxiety, depression), physical disturbances (motor control impairment, excessive muscle tension), pain syndrome characteristics (duration, intensity) and physical disability in patients with chronic low back pain. IL-10 and IL-8 appeared as two of the most characteristic cytokines. It is interesting to note that in literature studies approved a role of IL-10 in the pathogenesis of chronic, widespread pain syndrome, but IL-8 played its role in the pathogenesis of radicular pain syndrome in patients with lumbar spine disk pathology [1, 2]. This finding reflects the unity of body and psyche, and the complexity of pain syndrome.

\section{CONCLUSIONS}

1. Musculoskeletal dysfunction - reduced lumbar spine and pelvic motor control and excessive muscle tension - for patients with chronic low back pain is connected both with physical and psycho-emotional factors, therefore they should be taken into account both when evaluating functional tests and during the treatment process.
2. Studies of cytokines extend the understanding about bio-psycho-social aspects of chronic pain syndrome pathogenesis therefore improving the process of assessment, clinical reasoning and therapy.

\section{ACKNOWLEDGEMENT}

Immunological studies were carried out in collaboration with the Institute of Experimental and Clinical Medicine, University of Latvia, in the frameworks of the Research project of University of Latvia "New approaches to the diagnostics of exogenous health risk factors induced disturbances" (project leader: Pēteris
Tretjakovs). We are grateful to Pēteris Tretjakovs, Antra Jurka, Irisa Plosko for practical help and advice during research process.

We would also like to thank all colleagues in rehabilitation centre Ligatne who have co-operated in the research process.

\section{REFERENCES}

1. Seyler, N., Valenza, R., Stock, M. et al. (2006). Reduced levels of antiinflammatory cytokines in patients with chronic widespread pain. Arthritis Rheum, 54 (8), 2656-2564.

2. Miyamoto, H., Saura, R., Harada, T., Doita, M., Mizuno, K. (2000). The role of cyclooxygenase-2 and inflammatory cytokines in pain induction of herniated lumbar intervertebral disc. Kobe Journal of Medical Sciences, 46 (1-2), 13-28.

3. Manek, N. J., MacGregor, A. J. (2005). Epidemiology of back disoders: Prevalence, risk factors, and prognosis. Current Opinions in Rheumatology, 17 (2), 134-140.

4. Nachemson, A. L., Jonsson, E. (2000). Neck and Back Pain: The Scientific Evidence of Causes, Diagnosis, and Treatment. Philadelphia: Lippincott Willams \& Wilkins.

5. Freburger, J. K., Holmes, G. M, Agans, R. P. et al. (2009). The rising prevalence of chronic low back pain. Archives of Internal Medicine, 169 (3), 251-258.

6. Keefe, F. J., Rumble, M. E., Scipio, C. D. (2004). Psychological aspects of persistent pain: Current state of the science. Journal of Pain, 5, 195-211.

7. Linton, S. J. (2005). Understanding Pain for Better Clinical Practice. A Psychological Perspective. Pain Research and Clinical Management. Elsvevier, Edinburgh.

8. Waddell, G. (2004). The Back Pain Revolution. 2nd ed. Edinburgh: Churchill Livingstone.

9. Ancane, G., Smite, D. (2011). Die Bedeutung emotionaler Belastung fur das Schmerzsyndrom bei Patients mit chronischen Kreuzschmerz. Arztliche Psychotherapie und Psychosomatische Medizin, 6, 49-55.
10. Gatchel, R. J. (2001). A biopsychosocial overview of pretreatment screening of patients with pain. Clinical Journal of Pain, 17 (3), 192-199.

11. Peng, B., Wu, W., Li, Z., Guo, J., Wang, X. (2007). Chemical radiculitis. Pain, 127 (1-2), 11-16.

12. Watkins, L. R, Maier, S. F. (2000). The pain of being sick: Implications of immune-to-brain communication for understanding pain. Annual Review of Psychology, 51, 29-57.

13. Mens, J. M. A., Vleeming, A., Snijders, C. J., Koes, B., Stam, H. J. (2001). Reliability and validity of the active straight leg raising test in posterior pelvic pain since pregnancy. Spine, 26, 1167-1171.

14. Hardcasle, P., Nade, C. (1985). The significance of the Trendelenburg test. Journal of Bone and Joint Surgery, 67, 741-746.

15. Zigmond, A. S., Snaith, R. P. (1983). The hospital anxiety and depression scale. Acta Psychiatrica Scandinavica, 67, 361-370.

16. Ware, J. E., Snow, K. K., Kosinski, M. (1993, 2000). SF-36 Health Survey: Manual and Interpretation Guide. Linkoln RI: QualityMetric Incorporated.

17. Ohrback, R., McCall, W. D. (1996). The stress-hyperactivity-pain theory of myogenic pain. Pain Forum, 118, 238-247.

18. Pincus, T., Burton, A. K., Vogel, S., Field, A. P. (2002). A systematic review of psychological factors as predictors of chronicity/disability in prospective cohorts of low back pain. Spine, 27, E 109-120.

19. Fisher, K., Johnston, M. (1996). Emotional distress as a mediator of the relationship between pain and disability: An experimental study. British Journal of Health Psychology, 1, 207-218. 


\section{SERGANČIŲJŲ LĖTINIO NUGAROS JUOSMENINĖS DALIES SKAUSMO SINDROMU GRIAUČIŲ RAUMENŲ DISFUNKCIJOS, EMOCINIO IŠSEKIMO IR CITOKINŲ SĄSAJOS}

\section{Daina Šmite', Gunta Ancāne², Pēteris Tretjakovs ${ }^{3}$}

Rigos Stradins universitetas, Reabilitacijos katedra ${ }^{1}$

Rigos Stradins universitetas, Psichoterapijos ir psichosomatinès medicinos katedra ${ }^{2}$

Rigos Stradins universitetas, Eksperimentinès ir klinikinès medicinos institutas ${ }^{3}$

\section{SANTRAUKA}

Nepaisant įvairių gydymo metodų, maždaug 30\% asmenų ūmus nugaros skausmas virsta lètiniu, kuris kartu su sukeliama negalia žaloja ligonį, kelia rūpesčių sveikatos priežiūros sistemos darbuotojams ir pačiai visuomemei.

Tikslas - išanalizuoti sergančiųjų lètinio nugaros skausmo sindromu griaučių raumenų disfunkcijos, emocinio išsekimo, su tuo susijusios negalios ir visa tai lemiančių neuroimunologinių patofiziologinių mechanizmų sąsajas.

Tirti 43 ligoniai, kurių vidutinis amžius - $45 \pm$ 1,3 metų ir jiems diagnozuota juosmeninès stuburo dalies slankstelių disko patologija, dèl kurios pastarieji kenčia lètini skausmą ir su tuo susijusį emocinį išsekimą.

Visi ligoniai buvo kompleksiškai i̇vertinti taikant juosmeninės dalies ir dubens judesių valdymo testus, raumenų ir raiščių apčiuopą, Ligonių nerimo ir depresijos skalę bei imunologini kraujo tyrimą nustatant citokinų kiekį.

Tyrimas patvirtino $(p<0,05)$ judesių valdymo ir apčiuopos testų rezultatų, emocinio išsekimo ir skausmo intensyvumo sąsajas. Taigi ligonių, kenčiančių lètini nugaros juosmeninės dalies skausmą, griaučių raumenų disfunkcija susijusi tiek su fiziniais, tiek su psichoemociniais veiksniais. I visa tai reikia atsižvelgti taikant funkcinius testus ir gydymą. Kita kliniškai svarbi išvada yra ta, kad tokių ligonių fizinès veiklos ribotumą sukelia ir sutrikęs judesių valdymas, ir padidèjusi depresija. Tai svarbu planuojant reabilitaciją. Kai kurie citokinai (TNF-a, IL-6, IL-8, IL-10, IL-12) susiję su emociniu ir fiziniu sutrikimu, skausmo sukeliamais požymiais bei fizine negalia. Dažniausiai pasireiškiantys citokinai yra IL-10 ir IL-8. Idomu tai, kad mokslinėje literatūroje IL-10 citokinas siejamas su plačiai išplitusio lètinio skausmo sindromo patogeneze, o IL-8 - su radikulitinio skausmo sindromo patogeneze, kai ligoniams diagnozuota juosmeninès dalies slanksteliu disko patologija. Kitais tyrimais taip pat akcentuojami biopsichosocialiniai veiksniai diagnozuojant ir gydant ligonius, kenčiančius lètinius skausmus.

Raktažodžiai: griaučių raumenų disfunkcija, emocinis išsekimas, lètinis skausmas, citokinai. 